\title{
Family Responsibilities and Career Rhythms for Female Lecturers of Diponegoro University : Patriarchal Culture Hegemony
}

\author{
Suyanto* and Setyadi, Ary \\ Faculty of Cultural Sciences, Diponegoro University, Semarang, Indonesia
}

\begin{abstract}
This paper aims to explain the relationship between family formation and family responsibilities with the career rhythms of female lecturers. The sampling technique is cluster sampling, followed by the stratified random sampling technique. This study selected a sample of Diponegoro University. The sample size calculation uses the Krejcie and Morgan technique. The number of study respondents was 156 female lecturers. The results showed that family formation was related to career rhythms. The shorter the age of marriage, the more children they have, the lower the age of the first and last child, the slower the career rhythm. The relationship between family responsibility and career rhythm is negative, meaning that the higher the allocation of time, energy, and mind for the family, the lower the rhythm of his career. Most female lecturers work on their own various domestic activities. These activities include service to all family members, especially the preparation of food and work or school (for their children), maintenance of cleanliness and beauty of the house, and the provision of raw materials and consumption for all family members. Although institutional support is not gender discriminatory, female lecturers in developing careers with male lecturers do not equivalent. This shows that Undip female lecturers cannot take advantage of the various opportunities and opportunities available for career development. This is more due to the outpouring of energy, mind and attention to domestic activities (family) because children and families are more valuable than work for female lecturers. This is inseparable from the hegemony of patriarchal culture which is fertile and well-established in Indonesia in general and in Undip in particular.
\end{abstract}

Keywords: career rhythms, female lecturers, family formation, family responsibilities, patriarchal culture.

\footnotetext{
*Corresponding author: suyanto@live.undip.ac.id
} 


\section{Introduction}

Various instruments for the elimination of discrimination against women in various aspects of life in general and work in particular have long been adopted by Indonesia, such as $C E D A W$ [1], WID, GAD, and finally Gender Mainstreaming [2]. However, the real condition shows that the career development of women, especially female lecturers, in achieving functional (academic) and structural that higher positions are increasingly difficult.

On the other hand, women when studying generally have better academic achievement than men but that achievement is reversed with men when working [4]. Abele even described the journey between study and work of women as a brilliant educational biography developed into a poor occupational biography [5]. This shows that the success of women when working faces various obstacles originating from the domestic and public sectors. In the domestic sector, the biggest obstacle is related to children [6]. In addition, women are also faced with sociocultural constraints [7] and institutional (structural) resources [8]. According to research by Nick Foster and Jogan, more than 80 percent of professors at United Kingdom University and Slovenia are male [9]. These constraints stem from patriarchal culture. Patriarchal culture describes the form of organization in which fathers have dominance over all other family members and control all aspects of life. Patriarchy is the "law of the father" which includes all women's activities as a symbolic expression of the father. Patriarchy includes the relationship of actors and institutions as male domination at the level of the individual to the level of society, that is, usually men hold positions of power in all aspects of life. This dominance comes from the ownership of wealth and sources of income of men as the first and main source. In the end, patriarchy becomes an ideology. As an ideology, patriarchy operates closely related to the cultural value system of the local community [10]. This is what ultimately in gaining access, control, benefits, and participation of women and men in various aspects of life, including lame career development. It is this situation that in developing women's careers is said to face a glass ceiling, a discriminatory practice that prevents women from rising to executive positions [11], like other top structural and academic positions.

Inequality, according to one contemporary feminist theory, the theory of structural oppression, the basis of the subordination of women by men is the family because in the family concept of property and servants (family-Latin language) was first raised [12] . Although various efforts to eliminate discrimination against women are carried out, but not as a female lecturer in career development is equivalent to her colleague, male. Therefore, according to the writer, a study is needed to explore the root of the problem of inequality in the career development of women, especially female lecturers. In line with the theory of structural oppression, the main factor influencing the career rhythm of female lecturers is the family and its complexity. Therefore, this research will focus on the relationship of a woman's family responsibilities to her career rhythm.

Based on the background of the problem, this study seeks to identify and explain things that are obstacles in the career development of female lecturers at the family level. The objectives of this study are explains family responsibilities in relation to the career rhythm of female lecturers. 
The term career is conceptualized as a series of roles, status, and position achieved by someone [13]. In career patterns, the career rhythm is used. Career rhythm is defined as how quickly the officer climbed the career ladder and achieved certain beliefs, namely the time period for achieving career events, which related to the rank, position, educational status that has implications for the role given by the organization to him. The timeframe for achieving that event is a transit time, whose operation is the amount of time an individual expects to remain in a given position (a certain position) before advancing to the next position in the organizational career line [14]. This study framework observes the career rhythm of female lecturers linked to family responsibilities in the perspective of gender ideology.

According to Partini in relation to family responsibilities, the image of working women is negative because of ambivalence. The image of women is considered good if it can perfectly combine domestic roles (handling domestic work) and the public. Women in a career are not yet the main goal. Women's work motivation is to fill spare time and help the husband's income, not to self-actualization [15].

Of the various obstacles in women's career development, family constraints, especially those relating to children, are major and influential obstacles. When faced with these obstacles, women generally choose to sacrifice their careers over their families [16]. The success of children is a barometer of the success of women (mothers). Women are still expected to be able to maintain the "ideal image and myth of the mother". Women's success in a career can be achieved if they receive the support and encouragement of men (husbands). Thus, the success of women in a career is the success of the family concerned, not solely personal success.

As for Philipov explains that the ideological changes in contemporary society in the relationship of husband and wife shows a total shift from traditional societies to modern and postmodern values. In this shift, population issues play a significant role because their shifts produce a second demographic transition. As for the change in the value system towards increasing postmodern values in the form of (a) emphasis on individual autonomy; (b) rejection of all forms of institutional control and power; and (c) increasing expressive values related to self-realization, self-fulfillment, and seeking recognition (self) [17].

\section{Methods}

The research population was all female lecturers at Diponegoro University (Diponegoro University ((Universitas Diponegoro-Undip) (633 female lecturers). Large sampling in this study followed the Krejcie and Morgan techniques (156 female lecturer) [18]. The sampling of this study was using cluster sampling and stratified random sampling techniques. The data to be obtained in this study is secondary data and primary data. Secondary data were obtained from the Agency of Planning and Information Systems (APIS) and the Bureau of Civil Service and General Administration. Primary data collection is done by several methods, namely: non-participatory observation, structured interviews, and in-depth interviews. Data analysis uses quantitative and qualitative analysis. Quantitative analysis using descriptive statistical analysis which is used to explain the trend of patterns and 
distribution of variable characteristics. Qualitative analysis using descriptive analysis is to explain the variables of family responsibility and institutional support and resources. Descriptive analysis is followed by a categorical analysis which is used to categorize various factors influencing the career of female lecturers as well as theoretical interpretations.

\section{Results and Discussion}

Variables of the family responsibilities of this study include a variety of domestic activities which include: service to the husband in terms of eating and various work preparations; cleaning activities, beauty of the house, and the environment; and activities to provide raw materials and consumption for all family members. Data shows that in general female lecturers are highly involved in domestic activities. This is indicated by their frequency in three domestic activities more than 50 percent often and always carry out those three activities. Even for the activities of maintaining cleanliness, beauty of the house, and the environment; and the activity of providing raw materials and consumption for all family members, more than 75 percent of respondents stated that they often and always carry out these activities.

Table 1. Involvement of Female Lecturers in Domestic Activities

\begin{tabular}{|c|c|c|c|c|c|c|}
\hline \multicolumn{7}{|c|}{ Domestic Activity } \\
\hline \multirow[t]{2}{*}{ Frequency } & \multicolumn{2}{|c|}{$\begin{array}{c}\text { Husband service } \\
\text { (meals }+ \text { work } \\
\text { preparation) }\end{array}$} & \multicolumn{2}{|c|}{$\begin{array}{c}\text { Maintenance of } \\
\text { cleanliness }+ \\
\text { environmental beauty }\end{array}$} & \multicolumn{2}{|c|}{$\begin{array}{c}\text { Provision of raw materials } \\
+ \text { consumption of family } \\
\text { members }\end{array}$} \\
\hline & Amount & Percent & Amount & Percent & Amount & Percent \\
\hline 0 & 22 & 14.10 & 10 & 6.41 & 10 & 6.41 \\
\hline Never & 3 & 1.92 & 2 & 1.28 & 1 & 0.64 \\
\hline Sometimes & 37 & 23.72 & 27 & 17.31 & 15 & 9.62 \\
\hline Often & 52 & 33.33 & 70 & 44.87 & 46 & 29.49 \\
\hline Always & 42 & 26.92 & 47 & 30.13 & 84 & 53.85 \\
\hline Total & 156 & 100 & 156 & 100 & 156 & 100 \\
\hline
\end{tabular}

Source: Primary Data, 2019.

This study shows that attitudes and behaviors are the opposite of the conclusions of the Philipov research conducted in Western Europe and Eastern Europe above [19]. Indonesian women, especially female lecturers, cannot be separated from the various roles of women in traditional society or traditional roles, which are bound by various socio-cultural norms of Indonesia in general and Java, especially in various domestic activities, such as services to husbands and children in the preparation of meals and work or schools, the provision of raw materials for the consumption of family members, and maintenance of the beauty of the home and the environment. In Indonesian society in general and Java in particular, a woman in general has nature to subtle, gentle, patient, loyal, and clever reduce turmoil. 
Because of these qualities, they are more ideal as mothers and wives who have the main task of raising children and serving their husbands with patience and tenderness [20]. Such traits are internalized towards women through religion, social systems, politics, and education.

The involvement of female lecturers in conducting domestic activities is generally quite intensive, even though the female lecturer is a doctor or professor. They generally state that various domestic activities are an obligation. Almost all female lecturers are married and / or have children feel responsible for the various needs of their children and husband in the morning. It is customary that in the morning, husband and children go to work or school. To be comfortable in work or study (at school for their children), the necessary technical preparation is needed at work / school and breakfast. As one lecturer put it,

"I usually get up at 5:30 and then pray at dawn and accompany my child to sleep again until 7:30 because the children wake up at 7:30. Then bathe the children, cook for breakfast together. At 08.00-08.30 the children go to school, I cook for lunch, prepare lunch for the children, then take a shower and get ready for the office. I went to the office at 09.30, stopped by the children's school to deliver their supplies " (Yulianawati, 33 years).

What the women lecturer did above is not much different from the habits of senior lecturers based on their tenure. This lecturer once held office The Head of the Center for Real Work Lectures, but domestic activities such as preparing raw materials for consumption by family members, taking care of her husband and children, and maintaining the cleanliness and beauty of the house remain their main daily tasks, informants told researchers through in-depth interviews at below,

"I wake up at 4:30, the first activity I do is shopping, then cooking to eat, both morning, afternoon and evening, finished cooking, cleaning the house, showering and leaving the office, I usually leave the office at 6:30 because of the schedule I teach mostly at 7:00 am If on campus there is a time gap for teaching because my house happens to be not too far away from campus, I took the time to go home to accompany the children and husband's lunch, and leyeh-leyeh briefly. Going home for a short break while chatting with the children and husband, preparing dinner, cleaning up cutlery. After everything is neat, then I read or prepare lecture material, write articles, and so on and when I am sleepy I go to sleep" (Filsyani, 46 years).

For female lecturers, in general domestic activities are not only in the morning, but also sometimes during the day, taking time to go home for female lecturers who are not far from home and campus, and after work. After-work activities are also not much different from activities in the morning, namely cooking, preparing dinner, cleaning various appliances and conditions of the house and tidying various household appliances. The routine is carried out by female lecturers tirelessly and time and continuously who may greet his life, for life. That fact confirms that female lecturers, although they have worked in public space as professional-elite groups, cannot be separated from various roles according to cultural values manifested in the form of socio-cultural norms as women's roles or in the terms of Philipov as roles traditional gender [21].

This fact shows that female lecturers on the one hand must be responsible in the public space for their work but on the other hand must also be responsible in the domestic space 
for various domestic activities, something that is not done by their colleagues, male lecturers. In other words, female lecturers must face time and be full of totality in working in public spaces, the same as male lecturers, however, on the other hand female lecturers must also be responsible in the domestic space with all the complexity of their activities as work second shift. Thus, female lecturers in developing careers are hindered by domestic space. In addition, demands must be face time and total work in this public space is patriarchal [22]. This patriarchal system is a form of subordination of women to men and this is a real form of gender inequality [23].

Women's subordination from the aspect of social relations is not only a gender imbalance but more than that it is a form of gender oppression. The basis of women's subordinate relations is in the family (family in Latin 'servant'). In addition, the change of the social system of food gathering and hunting into the economic system of agriculture and animal husbandry gave birth to the concept of property. This concept explains that economic production resources are owned by men. In this economic system, men need labor (slaves, captives, women / wives, or children) and heirs who will inherit the property. Thus, the born family is first where men ask for women's services ${ }^{24}$.

\section{Conclusions and Policy Implications}

\subsection{Conclusions}

The patriarchal culture is proven to still hegemony female lecturers in developing their careers. This also happened in the career development of Undip female lecturers. The form of hegemony can be seen in the career rhythm of female lecturers which eventually accumulates at the rank level left behind by their peers, men on their way to the top of the lecturer career ladder, namely professors.

The relationship between family responsibilities and career rhythm is negative, meaning that the higher the time, energy, and mind allocation for the family, the lower the career rhythm. Most of the female lecturers do their own various domestic activities. The activities include services for all family members in terms of meals and work (school) preparation, maintenance of cleanliness and beauty of the home environment, and provision of raw materials and consumption for all family members.

\subsection{Policy Implications}

First, the career development of female lecturers is behind that of male lecturers. Therefore, there is a need for affirmative action for female lecturers. The policy mainly concerns the support of facilities such as feeding rooms, day care centers and early childhood education or kindergarten (Pendidikan Anak Usia Dini (PAUD)-Indonesian) for academicians so that female lecturers do not immediately return home after teaching. Thus, female lecturers can do work other than teaching to spur career rhythm towards the top of the career ladder (professor). Second, a positive discrimination policy also needs to be applied in research and community service. This needs to be done so that the number of women involved in the two matters increases. Third, special programs need to be developed for female lecturers' careers, such as the formation of female lecturer organizations so that they can help identify their various needs in building career rhythms and finally be able to develop their careers 
on a par with male lecturers. Finally, career development mentoring efforts are needed. Theoretically in career development mentoring there are many approaches that can be used.

\section{References}

1. Undang-undang Nomor 7/1984 tentang Penghapusan segala Bentuk Diskriminasi terhadap Perempuan dan Anak.

2. Nugroho, R. Gender dan Strategi Pengarusutamaannya di Indonesia. Yogyakarta: Pustaka Pelajar (2000).

3. Widyastuti, YSM dan Agung M Harsiwi. Produktivitas dan Kesempatan Aktualisasi Diri Dosen Perempuan. Laporan Penelitian dosen Muda (2004).

4. Crisanti-Sedyono. "Perempuan di Sektor Formal: Kerja Ya, Karier Tidak" dalam Perempuan Indonesia: Dulu dan Kini, Mayling Oey Gardiner (ed) hlm 212-231. Jakarta: Gramedia (1996).

5. Marks, G and Diane M Houston. "The Determinants of Young Women's Intention about Education, Career Development, and Family Life". Journal of Education and Work. (2002), Vol.15, No.3 pp. 321-336.

6. Partini. Peluang Pegawai Wanita untuk Menduduki Jabatan Struktural: Suatu Studi pada Pegawai Negeri Sipil Pemda DI Yogyakarta". Disertasi untuk Memperoleh Derajat Doktor dalam Sosiologi pada Universitas Gadjah Mada Yogyakarta (1999).

7. Marhaeni, AAIN. "Tingkat Keberdayaan Perempuan Bali dalam Jabatan Eselon di Provinsi Bali: Ditinjau dari Dimensi Internal dan Eksternal", Disertasi untuk memperoleh Derajat Doktor Ilmu Kependudukan pada Universitas Gadjah Mada, 6 Oktober (2011).

8. Anonymous. "Studi Pandangan Akademisi Wanita terhadap Kesetaraan Kesempatan dan Prospek Karier di Kopertis Wilayah VI Jawa Tengah". Makalah disampaikan pada Seminar Litbang Propinsi Jawa Tengah, 9 Sepetember (2003).

9. Widyastuti, YSM dan Agung M Harsiwi. 2004. Produktivitas dan Kesempatan Aktualisasi Diri Dosen Perempuan. Laporan Penelitian dosen Muda.

10. Partini. Peluang Pegawai Wanita untuk Menduduki Jabatan Struktural: Suatu Studi pada Pegawai Negeri Sipil Pemda DI Yogyakarta”. Disertasi untuk Memperoleh Derajat Doktor dalam Sosiologi pada Universitas Gadjah Mada Yogyakarta (1999).

11. Ibid

12. Ritzer, G. Modern Sociological Theory, $4^{\text {th }}$ (eds.). New York: The McGraw-Hill (1996).

13. Hughes,E.C. Institutional Office and the Person. American Journal of Sociology, 43, pp.404-413 (1937)

14. Corona, V P. "Career Patterns in the U.S. Army Officer Corps". Springer (2010).

15. Partini. Peluang Pegawai Wanita untuk Menduduki Jabatan Struktural: Suatu Studi pada Pegawai Negeri Sipil Pemda DI Yogyakarta". Disertasi untuk Memperoleh Derajat Doktor dalam Sosiologi pada Universitas Gadjah Mada Yogyakarta (1999).

16. Gash, V. "Sacrificing Their Career for Their Families?: An Analysis of Penalty to Motherhood in Europe". Springer Science+Bussiness Media (2009).

17. Philipov, D. "Family-related Gender Attitudes The Three Dimensions: Gender-role Ideology, Consequences for the Family. And Economic Consequnces". People, Population Change and Policies. Vol. 2, pp. 153-176 (2008)

18. Mantra, IB. Langkah-Langkah Penelitian Survai Usulan Penelitian dan Laporan Penelitian. Yogyakarta : Badan Penerbit Fakultas Geografi UGM (2000).

19. Philipov, D. "Family-related Gender Attitudes The Three Dimensions: Gender-role Ideology, Consequences for the Family. And Economic Consequnces". People, Population Change and Policies. Vol. 2, pp. 153-176 (2008) 
20. Hastuti. "Pembagian Kerja serta Peran Suami Istri dalam Pengambilan Keputusan di Rumah Tangga Pedesaan: Fenomena Dua Desa di Sisi Selatan Gunung Merapi Daerah Istimewa Yogyakarta". Disertasi, Universitas Gadjah Mada Yogyakarta (2009).

21. Philipov, D. "Family-related Gender Attitudes The Three Dimensions: Gender-role Ideology, Consequences for the Family. And Economic Consequnces". People, Population Change and Policies. Vol. 2, pp. 153-176 (2008)

22. Ritzer, G. Modern Sociological Theory, $4^{\text {th }}$ (eds.). New York: The McGraw-Hill (1996).

23. DuBois, E.C. "The Radicalism of the Women's Suffrage Movement", in Claire Goldberg Moses and Heidi Hartmann (eds.) (pp.42-51) U.S. Women in Struggle. Chcago: University of Illionis Press (1973/1995).

24. Langermann, PM and Jill Niebrugge.. "Contemporary Feminist Theory", in George Ritzer, Modern Sociological Theory, $4^{\text {th }}$ ed. New York: The McGraw-Hill (1996). 